\title{
Body-cult television advertisement recall among young women suffering from anorexia nervosa or bulimia nervosa'
}

\section{Recall de propagandas televisivas com culto à imagem em mulheres jovens com anorexia nervosa ou bulimia nervosa}

\author{
Alejandro del Moral-Agúndez ${ }^{\mathrm{a}}$ \\ (iD) https://orcid.org/0000-0002-1527-9599 \\ E-mail: delmoralळunex.es \\ Maria-Victoria Carrillo-Durán ${ }^{b}$ \\ (D) https://orcid.org/0000-0002-1256-8870 \\ E-mail: vicduranळunex.es \\ aUniversidad de Extremadura. Departamento de Dirección \\ de Empresas y Sociología. Badajoz, Spain \\ buniversidad de Extremadura. Departamento de Información \\ y Comunicación. Badajoz, Spain
}

\section{Abstract}

Advertising conveys an aesthetic model that seems to have a negative influence on young women. However, it is unclear whether the media are the cause, or only act as a reinforcement of disorders related to body image, such as those associated with eating behavior (anorexia or bulimia). This study measures the influence that advertising (measured by recall scores) during a television program has on women with eating disorders (anorexia or bulimia) compared to healthy women. Experimental study of exploratory nature performed on a sample of young women with eating disorders and a control group. The influence of advertising was estimated by recall scores, obtained after viewing a real television program, which included two commercial breaks containing two kinds of ads: body cult advertising (showing thinness or promoting it) and neutral advertising. Young women with eating disorders better recall advertisements showing thinness and products for weight loss and pay less attention to other types targeted at their age and gender group. Television advertising seems to be more of a reinforcement for these women who are already dissatisfied with their body, rather than a direct cause of their body image disorder.

Keywords: Eating Disorders; Body Image; Mass Media; Advertising Recall.

\section{Correspondence}

Alejandro del Moral-Agúndez

Universidad de Extremadura. Departamento de Dirección de Empresas y Sociología. Av. de Elvas, s/n, Badajoz, Spain. CP 0607 .

1 Funding: This research has been co-financed by the Extremadura Government and FEDER fund (European Regional Development Fund) (Code: GR15007). 


\section{Resumo}

A publicidade transmite um modelo estético que parece exercer uma influência negativa nas mulheres jovens. No entanto, não está claro se a mídia é a causa ou se atua apenas como um reforço de distúrbios relacionados à imagem corporal, como os associados ao comportamento alimentar (anorexia ou bulimia). Este estudo mede (por pontuação de recall) a influência que a publicidade mostrada durante um programa de televisão exerce sobre mulheres com transtornos alimentares (anorexia ou bulimia) em comparação com mulheres saudáveis. Estudo experimental de caráter exploratório realizado em uma amostra de mulheres jovens com distúrbios alimentares e um grupo de controle. A influência da publicidade foi estimada por pontuação de recall, obtida após a exibição de um programa de televisão, que incluía dois intervalos comerciais contendo dois tipos de anúncios: publicidade de culto ao corpo (mostrando ou promovendo a magreza) e propaganda neutra. As mulheres jovens com transtornos alimentares se lembram melhor dos anúncios que cultuam a magreza e produtos para perda de peso e prestam menos atenção a outros tipos destinados à sua idade e sexo. A publicidade na televisão parece ser mais um reforço para essas mulheres que já estão insatisfeitas com seu corpo, e não uma causa direta de seu distúrbio de imagem corporal.

Palavras-chave: Transtornos Alimentares; Imagem Corporal; Meios de Comunicação de Massa; Recall de Publicidade
The study of the relationship between the woman's body and her body image has occupied an important place in social research, both theoretically and empirically (Perloff, 2014). Concern about appearance is sometimes so important that the subject makes decisions that affect their health in trying to achieve unnatural results. This is the case of anorexia nervosa and bulimia nervosa, ${ }^{2}$ behavioural eating disorders whose appearance and development have a crucial cultural component (Toro, 1996), and are characterized by a physical and mental struggle in order to achieve an ideal of thinness.

Several authors (Cafri et al., 2005; Coleman, 2008; Ferguson et al., 2014; Smolak; ChunKennedy, 2015) have argued that, in our culture, the socio-cultural environment influences body image. Thus, in accordance with the theory of social comparison (Festinger, 1954), the social context becomes the perfect substrate for the generation of divergences in the formation of our self-image when comparing ourselves with members of nearby groups (Cattarin et al., 200o). This is especially the case with young women (Kozar; Damhorst, 2009).

In this sociocultural environment, the media can have a certain influence on body image (Cohen, 2006; Grabe; Ward; Hyde, 2008; Hausenblas et al., 2013). Certainly, the media (television and the press, especially) constitute one of the most important channels for transmitting the current aesthetic body model (Levine; Murnen, 2009; Rodríguez; Cruz, 2008), and seem to have an influential role in the formation of the aesthetic values adopted by society (Harrison, 2000; Harrison; Cantor, 1997; Levine; Harrison, 2004). However, it seems to be unclear whether the media act as a cause, or only as a reinforcement, of body-related disorders, such as those associated with eating behaviour, especially anorexia nervosa and bulimia nervosa (Ferguson, 2013; Levine; Murnen, 2009).

2 Anorexia nervosa is an eating disorder characterized by weight loss (or lack of appropriate weight gain in growing children); difficulties maintaining an appropriate body weight for height and age; and, in many individuals, distorted body image. People with anorexia nervosa generally restrict the number of calories and the types of food they eat (www.nationaleatingdisorders.org, 2019).

Bulimia nervosa is a serious, potentially life-threatening eating disorder characterized by a cycle of bingeing and compensatory behaviors such as self-induced vomiting designed to undo or compensate for the effects of binge eating (www.nationaleatingdisorders.org, 2019). 
Young women seem to be especially vulnerable to the messages in the media that show thinness as being ideal (Jiménez; Silva, 2010; Posavac; Posavac; Weigel, 2001), as they tend not to adopt a critical attitude towards what they see (Botta, 1999). Various studies have concluded that the effect of showing images of thinness is stronger on young women with previous body dissatisfaction, as is the case of those diagnosed with some form of behavioural eating disorder (Bessenoff, 2006; Rodgers; Chabrol, 2009; Tiggemann; McGill, 2004). However, we should not forget that such images may also have a negative impact on healthy young women, and even on older women (Cattarin et al., 200o; Gearhardt et al., 2014; Tucci; Peters, 2008).

\section{Advertisement recall and dissatisfaction with body image}

Research on the media and eating disorders has generated many studies related to the intensity and frequency of media consumption, but there is a lack of studies analysing specific content - for example, the types of advertising that could have negative effects, such as causing discomfort to one's body image (Levine; Murnen, 2009).

The relationship between advertising communication and the perception of one's body image may seem clear, since, in many cases, the advertising presents images close to an ideal of thinness (Frith; Shaw; Cheng, 2005) that could catch the attention of any young woman. This fact led us to study the relationship between what may be called body cult advertising and the problems linked to body image dissatisfaction which can result in eating disorders.

Body cult advertising is taken to be all those advertisements featuring either products aimed at improving body image (slimming, cosmetics, dietary...) or body stereotypes close to the ideal of perfection even though they do not directly promote products related to beauty or slimming. Therefore, one can differentiate between thinness-promoting ads (advertising of products that promote thinness) and thinness-depicting ads (advertising that shows images in which thinness is prominent) (Harrison; Cantor, 1997).

Research on the media's influence on eating disorders has in most cases focused on the direct exposure to body cult advertising in different formats (Seifert; Arnell; Kiviniemi, 20o8; Trampe; Stapel; Siero, 2007) and media, such as television (Groesz; Levine; Murnen, 2002; Lavine; Sweeney; Wagner, 1999; Myers; Biocca, 1992). In these studies, certain advertisements or images related to body image are isolated and placed outside their real context, which is within the medium, and accompanied by other advertisements aimed at the same target public but unrelated to body cult. These studies generally conclude that direct exposure to stimuli associated with beauty or slimming causes increased guiltiness about having an imperfect body (Groesz; Levine; Murnen, 2002; Harrison, 2000; Harrison; Hefner, 2006).

Some of the research carried out so far (Frith; Shaw; Cheng, 2005; Groesz; Levine; Murnen, 2002; Halliwell; Dittmar; Howe, 2005; Heinberg; Thompson, 1995; Myers; Biocca, 1992; Park, 2005; Seifert; Arnell; Kiviniemi, 2008; Trampe; Stapel; Siero, 2007) has focused on measuring the direct influence of body cult advertisements, ignoring the effect of other types of advertisements. This study, however, considers that the public is exposed not only to advertisements related to body cult, but also to others that may be of interest to the young female population, both those affected and those unaffected by eating disorders. In addition, we consider that, more than the exposure to advertising, the attention the subject paid to it should be evaluated as being a more reliable predictor of adolescents' socialization induced by the mass media.

According to the literature, ad recall ${ }^{3}$ is a relatively valid and reliable measure of the impact of advertising (Krugman, 200o; Mullarkey; Danaher, 2003). Recent studies support the use of quantitative measures of recall, for example, in the analysis of the relationship between images in the media that show the ideal of thinness and women's dissatisfaction with their own

\footnotetext{
3 Recall is the action or faculty of remembering something learned or experienced and ad recall is a measure of advertising effectiveness in which a sample of respondents is exposed to an ad and then at a later point in time is asked if they remember the ad (Keller, 1987).
} 
bodies (Jiang; Vartanian, 2016), or in the study of the relationship between obesity and food advertising (Gearhardt et al., 2014). We therefore consider advertising recall, the measure used in this study, to be a valid indicator of the influence of the message broadcast to the audience.

\section{Objectives and research assumptions}

This study explores in depth the influence of advertising measured through recall with a group that is particularly sensitive to suffering dissatisfaction with their body image (diagnosed with an eating disorder), and with a control group of unaffected women (not diagnosed). A selection of real and diverse (not only with body cult related content) advertisements was chosen and they were broadcast within the context of a real television program.

The objective of our study was to assess, through recall, the degree of attention paid by a group of young women to the various advertisements broadcast, whether or not of a body cult type. The research was carried out under two novel principles: (1) to not isolate the advertisements from the programming within which they are inserted, and (2) to expose the sample during their viewing not only to body cult associated stimuli, but also to other advertisements whose target audience matches their gender and age profile. This was done in order to overcome some of the limitations of previous studies (Cohen, 2006).

\section{Research assumptions}

Research assumption (RA) 1: Among young women diagnosed with an eating disorder, body cult advertising (products or images) and advertising with sensitive images for this group are recalled equally as is the advertising of products targeted at a young female public.

From this premise, and considering the exploratory nature of this research, the notion is that, apart from the eating disorder that the study's participants suffer from, they are also people who are likely to identify themselves not only with images that show or encourage body cult but also with any other image that shows situations or people close to their own reality as young women. It is to be expected that the sample would recall with similar intensity, advertisements that present situations or products typical of their age group (e.g., mobile phones, feminine hygiene, NGOs...) as well as advertisements of body cult (product or images) or with sensitive images.

RA2: Body cult advertising (products or images) as well as advertising with sensitive images are recalled equally by young women diagnosed with an eating disorder than by undiagnosed young women (control group).

Given the great importance that the current social context gives to body image, it seems logical to think that all young women (whether diagnosed or not with an eating disorder) react with a certain intensity to body cult advertising.

This premise holds that the impact, measured through recall, of body cult advertising (or advertising with sensitive images) on young women with some kind of eating disorder (diagnosed) is not significantly different from that on women of the same age profile but with no eating related problems (not diagnosed).

Table 1 summarizes the two premises that are addressed in this study, distinguishing between body cult advertising (products or images to promote beauty and thinness), advertising with sensitive images, and advertising targeted at a young female public, and between young women diagnosed with an eating disorder and a control group.

Table I-Research assumptions: Level of advertising recall \begin{tabular}{lll} 
& \multicolumn{2}{c}{ Advertising recall } \\
\cline { 2 - 3 } $\begin{array}{l}\text { Body cult advertising } \\
\text { (categories I \& 2) }\end{array}$ & $\mathrm{a}$ & $\mathrm{d}$ \\
\hline $\begin{array}{l}\text { Advertising with sensitive } \\
\text { images (category 3) }\end{array}$ & $\mathrm{b}$ & $\mathrm{e}$ \\
\hline $\begin{array}{l}\text { Advertising aimed at young } \\
\text { women (category 4) }\end{array}$ & $\mathrm{c}$ & $\mathrm{f}$ \\
\hline
\end{tabular}

RAI: $a=b=c ; R A 2: a=d$ and $b=e$ 
Methods

For this study, we counted on the participation of a sample of young women selected from the patients in the eating disorders unit of the University Hospital in Badajoz, Spain. For control purposes, we also included a group of women not diagnosed with any eating disorder. In total, there were 22 women diagnosed with eating disorders (anorexia nervosa and bulimia nervosa) and 9 undiagnosed women. The reason for restricting the study to women is because of the proliferation of eating disorders among women and their greater predisposition towards body cult stimuli.

The participants were aged between 15 and 36 years. Most (77.4\%) were in the range of 16-22 years, with a mean of 20.6 years, and no difference between the diagnosed group and the control group. Regarding the size of the sample, in numerous experimental studies a sample size of around 30 participants has been considered sufficient (Seifert; Arnell; Kiviniemi, 2008).

The procedure developed was similar to that used in other studies (Gearhardt et al., 2014; Jiang; Vartanian, 2016) and included two blocks of advertising within the context of an episode from a television series. We chose an episode of Friends (approximately 25 minutes long) about the preparations for the wedding of one of the main characters with a plot that had no apparent connection with our research. This television series was popular and has always been well received by the audience. It represents different profiles of men and women in accordance with their physical and psychological characteristics.

In this episode, we included two commercial breaks, each of about two minutes long containing nine advertising spots. These spots were shown once each. All the advertisements were real and had been broadcast during the same period on Spanish generalist television channels. Our aim was to reproduce as closely as possible the actual conditions of the young women's exposure to advertising. Furthermore, when a recall experiment is conducted under conditions close to reality, its efficacy is greater (Terry, 2005). We conducted the experiment in hospital facilities, in the case of the diagnosed group, but in an external facility, in the case of the control group.

We chose the advertisements for this study in accordance with the five categories established as the basis of the research, which will be explained in the next subsection. Specifically, we selected 18 real advertisements (Table 2 provides a brief description of them).

After viewing the video and without prior notification, we asked them to write down all those advertisements which they recalled having seen during the episode. They had to note down spontaneously the product type and brand, and the advertisement's content that they recalled (for example: First advertisement recalled - Type of product: perfume; Brand: Agatha Ruiz de la Prada. Content recalled: A group of young women in an idyllic setting, like a wood in a fairy tale).

Many factors may condition the results of an advertising recall test. The placement of the spot in the advertising block is a very important factor. To avoid the bias that this factor may cause in the results, during this study the body cult advertisements did not occupy the first or last position of each block, as these positions tend to favour recall (Terry, 2005).

The research thus assesses, in a controlled environment, the advertising impact of a group of advertisements according to their content (five differentiated categories) and to the health status of the audience (a group diagnosed with an eating disorder and a control group). We measured the advertising impact through spontaneous (unaided) ad recall. The study complied with the ethical principles of the Declaration of Helsinki.

\section{Category selection}

We grouped the advertisements into five categories. The first two in accordance with the classification of body cult advertising of Harrison and Cantor (1997):

- Category 1 - Body cult products. The advertisements in this category are those that promote body cult (thinnesspromoting ads), that is, ads of products for slimming or to help lose weight (light 
or low-calorie products) or ads of face and body beauty products.

- Category 2 - Body cult images. These advertisements are those that transmit body cult images (thinness-depicting ads), ads that, without being directly related to weight loss or beauty, are accompanied by images which convey a body cult message, for example, advertisements with extremely thin models.

- Category 3 - Sensitive images. Here are included those advertisements that do not show body cult images or products in a strict sense, but whose content (products, behaviour, or messages) may be particularly sensitive for those affected by an eating disorder. Examples are advertisements of high-calorie products (e.g., chocolates), or advertisements that use the context of beauty, but do not convey an interest in body cult (e.g., a lottery advertisement featuring a beauty contest in which anyone could win).

- Category 4 - Young female public. Here are included advertisements of products specific to the tastes and interests of young women (colognes, perfumes, feminine hygiene, NGOs...).

- Category 5 - Neutral. Included in this group are those advertisements with content unrelated to the elements being analysed in this research. We used them to reproduce the actual conditions of watching a television commercial break.

Table 2 - Advertisements viewed, classified by content

\section{Categories Brand, type of product, and content}

1. Body cult products I.- Bioslim. Slimming product that helps to reduce weight.

2.- L'Oreal. Cream for mature skin. Starring Claudia Schiffer and with the slogan Because I'm worth it.

$\begin{array}{ll}\text { 2. Body cult images } & \text { 3.- Mango. Cologne. The model starring is extremely thin. } \\ \text { 4.- Agatha Ruiz de la Prada. Perfume. It shows a group of thin girls in an idyllic setting. }\end{array}$

3. Sensitive images $\quad$ 5.- Nestlé. Chocolates. Highly desired product but forbidden for being very caloric.

6.- Canal Cocina. Themed television channel. Strongly related with food.

7.- Who knows who? Board game. It shows a typical behaviour of those suffering from an eating disorder. A young woman, during the night, binges in front of the fridge, and sucks on a cake mold.

8.- CD Rosa. Promotional space for a record of a popular Spanish singer who had won a talent show to discover new voices. The singer became famous despite being overweight, and therefore was erected as a symbol of the possibility of achieving success despite one's physique.

9.- Di-4. Vacuum cleaner. The advertisement plays to women's self-esteem and breaks with the old gender roles. A woman tests the product's power by vacuuming her husband who is lying on the couch while she does the household chores.

10.- National Lottery. Sweepstakes. Shows the prize giving in a beauty contest (Misses).

4. Young female
II.- Evax. Sanitary towels. A well-known Spanish actress is the protagonist.
12.- The PhoneHouse. Mobile phone shop. Products that greatly attract young people.
13.- Foundation for Help Against Drug Addiction (FAD). NGO that calls attention to drugs being
a serious problem mostly affecting young people.
14.- Doctors Without Borders. NGO that helps the Third World.

15. - Duracell. Batteries.
16.- Oral B. Toothbrush.

First and last

advertisement

18.- Baileys. Liqueur. It shows in a typically youthful context a group of young people in a bar.

17.- Lacoste. Man's perfume. It shows a naked man. 


\section{Results}

To assess the participants' level of involvement with the experiment, we first asked them to give their overall opinion on the episode they had seen. None of the young women seemed to think it was a bad or very bad episode. All in the diagnosed group rated it either in the middle of the scale $(50.0 \%)$, or as good or very good (50.0\%). The assessment of the control group (not diagnosed young women) was clearly more favourable $-100 \%$ of them rated it as good or very good (Table 3 ).

\section{Table 3-Involvement with the experiment}

\begin{tabular}{|c|c|c|c|}
\hline Variables & & Diagnosed (\%) & Control (\%) \\
\hline \multirow[t]{4}{*}{ I found the episode: } & Very good & 9.1 & 77.8 \\
\hline & Good & 40.9 & 22.2 \\
\hline & Normal & 50.0 & 0.0 \\
\hline & Total & 100 & 100 \\
\hline \multirow[t]{6}{*}{ The commercial breaks were long } & Not at all & 4.8 & 12.5 \\
\hline & A bit & 28.6 & 0.0 \\
\hline & Somewhat & 28.6 & 50.0 \\
\hline & Quite a bit & 23.8 & 25.0 \\
\hline & A lot & 14.3 & 12.5 \\
\hline & Total & 100 & 100 \\
\hline \multirow[t]{6}{*}{ The commercial breaks were boring } & A bit & 20.0 & 57.1 \\
\hline & Somewhat & 45.0 & 14.3 \\
\hline & Quite a bit & 20.0 & 14.3 \\
\hline & A lot & 15.0 & $14 \cdot 3$ \\
\hline & Total & 100 & 100 \\
\hline & & Diagnosed & Control \\
\hline \multirow[t]{3}{*}{ Number of advertisements recalled } & Mean & 3.14 & 4.11 \\
\hline & Median & 3 & 4 \\
\hline & Standard deviation & 2.01 & 1.17 \\
\hline
\end{tabular}

We also asked the participants to give their general opinion of the commercial breaks in two characteristics - duration and amenity. Although the breaks lasted for less than two minutes each, the young women generally qualified them as being long (66.7\% versus $87.5 \%$ in the control group) and boring ( $80 \%$ versus $42.9 \%$ in the control group) (Table 3 ). These assessments could indicate a negative bias towards the broadcasting of advertisements, especially in the diagnosed group, which may negatively condition their advertising recall.

The mean number of advertisements recalled by the group diagnosed with an eating disorder was 3.14 (standard deviation of 2.01), and slightly higher in the control group (4.11, with standard deviation of 1.17).
Based on the data above, we can say there was a positive predisposition of the participants in the experiment, which favours the reliability of the results.

\section{RAI - Advertising recall of young women diagnosed with an eating disorder $[a=b=c]$}

Recall is conditioned by the degree of involvement of the subject with the type of product advertised or with the content being shown (Harrison; Cantor, 1997). It is expected that young women diagnosed with eating disorders would pay special attention to body cult advertisements (Categories 1 and 2) and, given their disorder, to those presenting sensitive images (Category 3). However, because of their age, 
around 20 years old, they should also be interested in products particularly linked to this age group and appealing to them (Category 4). Therefore, as posited in Premise RA1, we expected that young women diagnosed with an eating disorder would have similar levels of recall of body cult advertising
(Categories 1 and 2), of advertising with sensitive images (Category 3), and of products aimed at the young female public (Category 4), and higher than that of other, neutral advertising. To test this premise, we calculated the mean degree of recall in each of these advertising categories (Table 4).

\section{Table ${ }_{4}$ - Advertisement recall scores}

\begin{tabular}{|c|c|c|c|c|}
\hline Categories & Advertisements & $\begin{array}{l}\text { Diagnosed } \\
(\%)\end{array}$ & $\begin{array}{c}\text { Control } \\
(\%)\end{array}$ & $\begin{array}{c}\text { Difference } \\
(\%)\end{array}$ \\
\hline \multirow[t]{3}{*}{ I. Body cult products } & $1-($ Bioslim: Weight loss $)$ & 27.3 & 22.2 & 5.1 \\
\hline & $2-\left(L^{\prime} O r e a l:\right.$ Face cream $)$ & $27 \cdot 3$ & 55.5 & -28.2 \\
\hline & Mean score & $27 \cdot 3$ & 38.9 & -11.6 \\
\hline \multirow[t]{3}{*}{ 2. Body cult images } & 3-(Mango: Cologne) & 36.4 & 22.2 & 14.2 \\
\hline & 4-(Agatha Ruiz: Perfume) & 4.5 & 0.0 & 4.5 \\
\hline & Mean score & 20.5 & II.I & 9.4 \\
\hline Categories I+2: Body cult advertising & Mean score & 23.9 & 24.9 & -1.0 \\
\hline \multirow[t]{7}{*}{ 3. Sensitive images } & 6-(Canal Cocina: TV Channel) & 36.4 & 33.3 & 3.1 \\
\hline & $8-($ Rosa: Singer $)$ & 22.7 & 22.2 & 0.5 \\
\hline & $9-(D i-4:$ Vacuum cleaner $)$ & 18.2 & 0.0 & 18.2 \\
\hline & 5-(Nestlé: Chocolates) & 13.6 & 0.0 & 13.6 \\
\hline & $7_{-}$(Who-knows-who? Board game) & 9.1 & 0.0 & 9.1 \\
\hline & $10-(\text { National Lottery })^{*}$ & 0.0 & 0.0 & 0.0 \\
\hline & Mean score & 20.0 & 11.1 & 8.9 \\
\hline \multirow[t]{5}{*}{ 4. Young female public } & $12-($ The PhoneHouse: Mobiles) & 18.2 & 77.8 & -59.6 \\
\hline & $13-(F A D: \mathrm{NGO})$ & 18.2 & 33.3 & -15.1 \\
\hline & $14-(D W B: \mathrm{NGO})$ & 18.2 & $33 \cdot 3$ & -15.1 \\
\hline & $11-($ Evax: Sanitary towels $)$ & 13.6 & $33 \cdot 3$ & -19.7 \\
\hline & Mean score & 17.1 & 44.4 & $-27 \cdot 3$ \\
\hline \multirow[t]{3}{*}{ 5. Neutral } & $15-$ (Duracell: Batteries) & 4.5 & 0.0 & 4.5 \\
\hline & $16-($ Oral-B: Toothbrush) & 0.0 & 22.2 & -22.2 \\
\hline & Mean score & 2.3 & 11.1 & 8.8 \\
\hline \multirow[t]{3}{*}{ First and last advertisement } & 17 -(Baileys: Liqueur) & 9.1 & 11.1 & -2.0 \\
\hline & $18-($ Lacoste: Perfume $)$ & 36.4 & $44 \cdot 4$ & -8.0 \\
\hline & Mean score & 22.8 & 27.8 & -5.0 \\
\hline
\end{tabular}

Note: The positive differences imply that the recall is greater among those diagnosed; the negative differences imply that the recall is greater among those who are healthy. ${ }^{*}$ Advertisement not considered when calculating the mean. 
The mean recall scores for the advertising categories make it impossible to confirm Premise RA1 (equal level of recall of body cult advertising, sensitive images advertising, and advertising aimed at the young female public, among the young women diagnosed with eating disorders). Thus, as one observes in Table 4, while advertisements with sensitive images (Category3) and those aimed at the young female public (Category 4) have similar, not very high, mean recall scores of $16.7 \%{ }^{4}$ and $17.1 \%$ respectively; the body cult advertisements (Categories 1 and 2) are better recalled, $\mathbf{2 3 . 9} \%$. Also, if we only consider body cult product advertisements (Category 1 ), the recall score is even higher, namely $27 \cdot 3 \%$.

In summary, it can be stated that young women with eating disorders recall body cult advertising (27.3\% and 20.5\% in Categories 1 and 2, respectively), especially when the product is one that promotes the body cult (Category 1), and advertising with content that is sensitive regarding their eating disorder (20.0\% in Category 3), better than advertising related to the interests of young women in general $(17.1 \%$ in Category 4) (Table 4). Following the terminology of Table 1 , we can say that $a>b>c$. Nonetheless, it must not be forgotten that the differences in recall between the various categories of advertisements do not seem to be large enough to be considered significant. A more robust conclusion would imply a new study.

Despite what has been said above, it is noteworthy that the diagnosed young women do not stop paying attention to and recalling the advertising aimed in general at their age group. Thus, the mean recall of Category 4 (advertising aimed at the young female public) is around $18 \%$, whereas the two neutral advertisements, of little interest for the profile of the participants, went largely unnoticed (i.e., the batteries ad was remembered by only $4.5 \%$ of the diagnosed group, and no woman remembered the toothbrush ad). This confirms that the involvement of the audience with the advertisements broadcast (because of both their gender and their age, as well as interests related to the disorder they suffer) conditions the level of recall.

This same analysis, but referring to the control sample, gives different results, but neither do these results comply with Premise RA1. Thus, the control group recalls the advertisements aimed at their age (Category 4) better than those of the body cult (Categories 1 and 2), and, in turn, the latter are better recalled than those containing sensitive images (Category 3). Following the terminology of Table 1, we can say that $c>a>b$.

\section{RA2 - Advertising recall: comparing diagnosed and undiagnosed young women with an eating disorder $[a=d, b=e]$}

Comparing the recall scores of the different categories between the young women diagnosed with an eating disorder and the control group, Premise RA2 seems at first to be verified (Table 4). Thus, body cult advertisements (Categories 1 and 2) are recalled in similar proportions by both groups $-23.9 \%$ and $24.9 \%$, respectively. The conclusion changes if we consider the sensitive image advertising (Category 3), which is clearly better recalled by the diagnosed group - $20.0 \%$ versus $11.1 \%$ for the control group. One also observes a great difference in recall between the two groups regarding the advertising aimed at the young female public (Category 4), with greater recall by the control group ( $44.4 \%$ versus $17.1 \%$ ).

Therefore, Premise RA2 appears to be verified only in part. Following the terminology used, we would say that $\mathrm{a}=\mathrm{d}$, but $\mathrm{b}>\mathrm{e}$ and $\mathrm{c}<\mathrm{f}$. However, a more detailed analysis that considers the recall of each advertisement individually leads us to conclude that Premise RA2 is not verified in the first case either (body cult advertising). The apparent equal recall of body cult advertisements (Categories 1 and 2) by the diagnosed and the control groups is not actually so. Rather, we should say that these kinds of ads are better recalled by the diagnosed young women (positive figures in the difference column of Table 4)

\footnotetext{
4 The National Lottery advertisement (see the description in Table 2), included in Category 3 (sensitive images), presents zero recall for both the affected and the unaffected young women. This result makes us believe that the lottery is a product of no interest for young women in general, despite the content of the advertisement being related in a certain way with beauty. With the elimination of this advertisement, the mean recall of Category 3 for those diagnosed with an eating disorder rises to $20.0 \%$.
} 
except for the facial cream advertisement (L'Oreal). The Mango cologne advertisement, starring a very thin model, is clearly better recalled by the diagnosed young women (36.4\% versus $22.2 \%$ ), as also are the slimming product Bioslim and the Agatha Ruiz de la Prada perfume.

The L'Oreal face cream advertisement (Category 1) presents a much higher level of recall in the control group than in the diagnosed group $(55.5 \%$ versus $27 \cdot 3 \%$ ). This unexpected result for an advertisement classified as body cult might be explained by young women diagnosed with an eating disorder having less interest in facial beauty than in beauty of the body. This result calls for further in-depth investigation.

Advertisements containing sensitive images (Category 3) are also better recalled by diagnosed young women. In this sense, the vacuum cleaner Di-4 stands out, which emphasizes self-esteem and breaks gender stereotypes; and also the Nestlé chocolates, a taboo food for anyone who wants to control their weight.

Regarding the advertisements targeted at the young female public (Category 4), we observed that they are clearly recalled less by the diagnosed young women (negative figures in the difference column of Table 4). Thus, young women with eating disorders recall far less the PhoneHouse advertisement (18.2\% versus $77.8 \%$ ). Young people's intense involvement with mobile telephony would seem to explain why this is by far the advertisement best recalled by the young women in the control group. As for the affected young women, their low recall could be explained by a progressive tendency towards social isolation. In a similar vein, the lower level of recall of the Evax advertisement (feminine hygiene products) by the diagnosed group (13.6\% versus $33.3 \%$ in the control group) could be due to the fact that especially young women with anorexia nervosa may suffer menstrual disruption and are consequently little interested in this type of product.

Therefore, Premise RA2, which posits equal levels of advertising recall by the diagnosed young women and by the control group, is not verified. The young women diagnosed with an eating disorder recall body cult advertisements and ads with sensitive content better than those in the control group (with the exception of the facial beauty advertisement), and recall worse than the control other advertisements targeted at young women or at women in general. In sum, following the terminology being used, one concludes that $a>d, b>e$, but $c<f$.

\section{Final considerations}

A priori, these results do not seem to go against those of previous studies regarding the greater impact of body cult advertising on a population that is sensitive to aesthetic issues, as is that of women suffering eating disorders (Bessenoff, 2006; Ferguson, 2013; Jiménez; Silva, 2010; Rodgers; Chabrol, 2009; Tiggemann; McGill, 2004). They do represent a step further along this research line, however, as the study measured the recall of certain body cult stimuli in a controlled context similar to reality, avoiding the concentration of body cult images. Although the differences in recall between the group diagnosed with eating disorders and the control group are not very large, the eating disorder group of young women recalled better than the control the advertisements related to beauty and slimming (except for the facial beauty advertisement). This result leads us to think that the ideal beauty of women diagnosed with an eating disorder seems to follow a pattern of a thin body, independently of facial beauty, which we consider to be of interest for future research.

As mentioned above, this study is a first step in the analysis of the influence of body cult advertising measured by recall, combining the presence of these stimuli with other non-body-cult advertisements that are aimed at this target public. In the absence of studies that evaluate at the same time the influence of body cult stimuli and of other stimuli which are close to the interests of the sample (young women in general), it appears from these results that body cult advertising acts more as a reinforcement for women previously dissatisfied with their bodies, as is the case of young women diagnosed by some eating disorder, than as a direct cause of the disorder, since we did not find the control group to present any marked tendency of recall in the same direction as the diagnosed group.

The level of recall of advertising related to slimming was higher in the diagnosed population. 
This supports the idea that the influence of such advertising is greater when the disorder already exists. Thus, we think that the mere presence of advertising, albeit of a body cult type, will not by itself attract the attention of young women if there is no predisposition on their part.

Finally, it must be noted that the interest of the diagnosed group of young women in advertising directly targeted at a young female public also seems to be mitigated by the adverse effect of their eating disorder. This lends support to the idea that their social isolation, rejection of their status of womanhood, and denial of their own sexuality, among other characteristics that young women diagnosed by eating disorders usually have (Toro, 1986), mean that it is the disorder itself which conditions their recall of certain stimuli and not the stimuli which condition their disorder.

\section{References}

BESSENOFF, G. R. Can the media affect us? Social comparison self-discrepancy and the thin ideal. Psychology of Women Quarterly, Thousand Oaks, v. 30, n. 3, p. 239-251, 2006. DOI: 10.1111/j.14716402.2006.00292.x

BOTTA, R. A. Television images and adolescent girls, body image disturbance. Journal of Communication, Hoboken, v. 49, n. 2, p. 22-41, 1999. DOI: 10.1111/j.146o-2466.1999.tbo2791.X

CAFRI, G. et al. The influence of sociocultural factors on body image: a meta-analysis. Clinical Psychology: Science and Practice, Hoboken, v. 12, n. 4, p. 421-433, 2005. DOI: 10.1093/clipsy.bpio53

CATTARIN, J. A. et al. Body image mood and televised images of attractiveness: the role of social comparison. Journal of Social and Clinical Psychology, New York, v. 19, n. 2, p. 220-239, 2000. DOI: 10.1521/jscp.2000.19.2.220

COHEN, S. B. Media exposure and the subsequent effects on body dissatisfaction, disordered eating, and drive for thinness: a review of the current research. Mind Matters: The Wesleyan Journal of Psychology, Middletown, v. 1, p. 57-71, 2006.
COLEMAN, R. The becoming of bodies: girls, media effects, and body image. Feminist Media Studies, Abingdon, v. 8, n. 2, p. 163-179, 2008. DOI: $10.1080 / 14680770801980547$

FERGUSON, C. J. In the eye of the beholder: thinideal media affects some, but not most, viewers in a meta-analytic review of body dissatisfaction in women and men. Psychology of Popular Media Culture, Washington, DC, v. 2, n. 1, p. 20-37, 2013. DOI: $10.1037 /$ aoo30 766

FERGUSON, C. J. et al. Concurrent and prospective analyses of peer, television and social media influences on body dissatisfaction, eating disorder symptoms and life satisfaction in adolescent girls. Journal of Youth and Adolescence, New York, v. 43, n. 1, p. 1-14, 2014. DOI: 10.1007/s10964-012-9898-9

FESTINGER, L. A theory of social comparison processes. Human Relations, Thousand Oaks, v. 7, n. 1, p. 117-140, 1954. DOI: 10.1177/001872675400700202

FRITH, K.; SHAW, P.; CHENG, H. The construction of beauty: a cross-cultural analysis of women's magazine advertising. Journal of Communication, Hoboken, v. 55, n. 1, p. 56-7o, 2005. DOI: 10.1111/j.146o-2466.2005.tbo2658.x

GEARHARDT, A. N. et al. Relation of obesity to neural activation in response to food commercials. Social Cognitive and Affective Neuroscience, Oxford, v. 9, n. 7, p. 932-938, 2014. DOI: $10.1093 /$ scan/nsto59

GRABE, S.; WARD, L. M.; HYDE, J. S. The role of the media in body image concerns among women: a meta-analysis of experimental and correlational studies. Psychological Bulletin, Washington, DC, v. 134, n. 3, p. 46o-476, 2008. DOI: 10.1037/0033-2909.134.3.46o

GROESZ, L. M.; LEVINE, M. P.; MURNEN, S. K. The effect of experimental presentation of thin media images on body satisfaction: a metaanalytic review. International Journal of Eating Disorders, Hoboken, v. 31, n. 1, p. 1-16, 2002. DOI: $10.1002 /$ eat.10005 
HALLIWELL, E.; DITTMAR, H.; HOWE, J. The impact of advertisements featuring ultra-thin or average-size models on women with a history of eating disorders. Journal of Community \& Applied Social Psychology, Hoboken, v. 15, n. 5, p. 406-413, 2005. DOI: 10.1002/casp.831

HARRISON, K. Television viewing, fat stereotyping, body shape standards and eating disorder symptomatology in grade school children. Communication Research, Thousand Oaks, v. 27, n. 5, p. 617-640, 200o. DOI: 10.1177/009365000027005003

HARRISON, K.; CANTOR, J. The relationship between media consumption and eating disorders. Journal of Communication, Hoboken, v. 47, n. 1, p. 40-67, 1997. DOI: 10.1111/j.1460-2466.1997. tbo2692.x

HARRISON, K.; HEFNER, V. Media exposure, current and future body ideals, and disordered eating among preadolescent girls: a longitudinal panel study. Journal of Youth and Adolescence, New York, v. 35, n. 2, p. 146-156, 2006. DOI: 10.1007/s10964-005-9008-3

HAUSENBLAS, H. A. et al. Media effects of experimental presentation of the ideal physique on eating disorder symptoms: a meta-analysis of laboratory studies. Clinical Psychology Review, Amsterdam, v. 33, n. 1, p. 168-181, 2013. DOI: 10.1016/j.cpr.2012.10.011

HEINBERG, L. J.; THOMPSON, J. K. Body image and televised images of thinness and attractiveness: a controlled laboratory investigation. Journal of Social and Clinical Psychology, New York, v. 14, n. 4, p. 325-338, 1995. DOI: 10.1521/jscp.1995.14.4.325

JIANG, M. Y.; VARTANIAN, L. R. The role of memory in the relationship between attention toward thin-ideal media and body dissatisfaction. Eating and Weight Disorders-Studies on Anorexia, Bulimia and Obesity, New York, v. 21, p. 57-64, 2016. DOI: 10.1007/s40519-015-0196-X

JIMÉNEZ, B. E.; SILVA, C. Risk for eating disorders, anxiety, depression and other emotions related to publicitary images exposure. Annals of Psychology, Lausanne, v. 26, n. 1, p. 11-17, 2010.
KELLER, K. L. Memory factors in advertising: The effect of advertising retrieval cues on brand evaluations. Journal of Consumer Research, Oxford, v. 14, n. 3, p. 316-333, 1987. DOI: $10.1086 / 209116$

KOZAR, J. M.; DAMHORST, M. L. Comparison of the ideal and real body as women age: relationships to age identity, body satisfaction and importance, and attention to models in advertising. Clothing and Textiles Research Journal, Thousand Oaks, v. 27, n. 3, p. 197-210, 2009. DOI: 10.1177/o887302Xo8326351

KRUGMAN, H. E. Memory without recall, exposure without perception. Journal of Advertising Research, Abingdon, v. 40, n. 6, p. 49-54, 2000. DOI: 10.2501/JAR-40-6-49-54

LAVINE, H.; SWEENEY, D.; WAGNER, S. H. Depicting women as sex objects in television advertising: effects on body dissatisfaction. Personality and Social Psychology Bulletin, Thousand Oaks, v. 2, n. 8, p. 1049-1058, 1999. DOI: 10.1177/01461672992511012

LEVINE, M. P.; HARRISON, K. Media's role in the perpetuation and prevention of negative body image and disordered eating. In: THOMPSON, J. K. (Ed.). Handbook of eating disorders and obesity. Hoboken: John Wiley \& Sons, 2004. p. 695-717.

LEVINE, M. P.; MURNEN, S. K. Everybody knows that mass media are/are not [pick one] a cause of eating disorders: a critical review of evidence for a causal link between media, negative body image, and disordered eating in females. Journal of Social and Clinical Psychology,

New York, v. 28, n. 1, p. 9-42, 2009. DOI: 10.1521/ jscp.2009.28.1.9

MULLARKEY, G. W.; DANAHER, P. J. Factors affecting online advertising recall: a study of students. Journal of Advertising Research, Abingdon, v. 43, n. 3, p. 252-267, 2003. DOI: 10.1017/So021849903030319

MYERS, P.; BIOCCA, F. The elastic body image: the effect of television advertising and programming on body image distortion in young women. Journal of Communication, Hoboken, v. 42, n. 3, p. 108-133, 1992. DOI: 10.1111/j.146o-2466.1992.tboo802.x 
PARK, S.-Y. The influence of presumed media influence on women's desire to be thin. Communication Research, Thousand Oaks, v. 32, n. 5, p. 594-614, 2005. DOI: 10.1177/0093650205279350

PERLOFF, R. M. Social media effects on young women's body image concerns: theoretical perspectives and an agenda for research. Sex Roles, New York, v. 71, n. 11, p. 363-377, 2014. DOI: 10.1007/s11199-014-0384-6

POSAVAC, H. D.; POSAVAC, S. S.; WEIGEL, R. G. Reducing the impact of media images on women at risk for body image disturbance: Three targeted interventions. Journal of Social and Clinical Psychology, New York, v. 20, n. 3, p. 324-340, 2001. DOI: $10.1521 /$ jscp.20.3.324.22308

RODGERS, R.; CHABROL, H. The impact of exposure to images of ideally thin models on body dissatisfaction in young French and Italian women. L'Encéphale-Revue de Psychiatrie Clinique Biologique et Thérapeutique, Amsterdam, v. 35, n. 3, p. 262-268, 2009. DOI: 10.1016/j. encep.2008.05.003

RODRÍGUEZ, S.; CRUZ, S. Insatisfacción corporal en adolescentes latinoamericanas y españolas. Psicothema, Oviedo, v. 20, n. 1, p. 131-137, 2008.

SEIFERT, A. L.; ARNELL, K. M.; KIVINIEMI, M. T. The relation of body dissatisfaction to salience of particular body sizes. Eating and Weight
Disorders, New York, v. 13, n. 4, p. 84-9o, 2008. DOI: $10.1007 / B F 03327510$

SMOLAK, L.; CHUN-KENNEDY, C. Sociocultural influences on the development of eating disorders and obesity. In: CHOATE, L. H. (Ed.). Eating disorders and obesity: a counselor's guide to prevention and treatment. Hoboken: Wiley, 2015. p. 1-20. DOI: 10.1002/9781119221708.ch1

TERRY, W. S. Serial position effects in recall of television commercials. The Journal of General Psychology, Abingdon, v. 132, n. 2, p. 151-164, 2005. DOI: 10.3200/GENP.132.2.151-164

TIGGEMANN, M.; MCGILL, B. The role of social comparison in the effect of magazine advertisements on women's mood and body dissatisfaction. Journal of Social and Clinical Psychology, New York, v. 23, n. 1, p. 23-44, 2004. DOI: 10.1521/jscp.23.1.23.26991

TORO, J. El cuerpo como delito. Barcelona: Ariel, 1996.

TRAMPE, D.; STAPEL, D. A; SIERO, F. W. On models and vases: body dissatisfaction and proneness to social comparison effects. Journal of Personality and Social Psychology, Washington, DC, v. 92, n. 1, p. 106-118, 2007. DOI: 10.1037/00223514.92.1.106

TUCCI, S.; PETERS, J. Media influences on body satisfaction in female students. Psicothema, Oviedo, v. 20, n. 4, p. 521-524, 2008.

\section{Authors' contribution}

Carrillo-Durán conceived the study. Del Moral-Agúndez analyzed data. Both authors contributed to the manuscript creation.

Received: 09/05/2019

Approved: 09/26/2019 